\title{
Design System of Student Registration and The Purchase of Musical Concert Ticket at Samuel Riedone Course \& Music Performance
}

\author{
Peryo Suliantino ${ }^{1}$, Andi Leo ${ }^{2}$ \\ ${ }^{1,2}$ Buddhi Dharma University, Information System, Banten, Indonesia
}

\begin{tabular}{|c|c|}
\hline SUBMISSION TRACK & A B S T R A C T \\
\hline $\begin{array}{l}\text { Recieved: Aug } 28,2020 \\
\text { Final Revision: Sept } 18,2020 \\
\text { Available Online: Sept 29, } 2020\end{array}$ & \multirow{5}{*}{$\begin{array}{l}\text { Music is an entertainment media for most people in the world. The existence of } \\
\text { music can help all work activities done by people.In the world of music itself } \\
\text { there are also various musical instruments that create a beautiful blend of sound } \\
\text { and calm the mind.Instruments that are very influential and can make the feeling } \\
\text { of a person feeling happy and happy among them is piano. A well-known private } \\
\text { piano course in BSD area called Samuel Riedone private Piano course, Prepare a } \\
\text { range of learning materials and a highly skilled and enjoyable teaching team. But } \\
\text { the name of the music course also has bureaucracy or administration that must be } \\
\text { run every day so that the running business process can be as expected. To } \\
\text { facilitate the manual business process is now more modern it will be created a } \\
\text { WEB-based information system that is able to assist in the daily business } \\
\text { process. The system will use the Term Frequency (TF) and Inverse Document } \\
\text { Frequency (IDF) methods to be able to process the data of many documents in the } \\
\text { business process from the music course, and by using the PHP programming } \\
\text { language and MySQL database to create the system.Designing of new Student } \\
\text { information system and purchasing concert tickets, already in accordance with the } \\
\text { needs and problems that arise at the course of Samuel Riedone Course \& Music } \\
\text { Performance. And also with the new student registration system and the purchase } \\
\text { of concert tickets based on this website, it is easy for users to make purchase } \\
\text { transactions for music concert tickets, and register themselves to be able to follow } \\
\text { the course at this place. }\end{array}$} \\
\hline KEYWORD & \\
\hline Designing, Website, Music Concerts, TF-IDF & \\
\hline CORRESPONDENCE & \\
\hline $\begin{array}{l}\text { E-mail: } \\
\text { suliantinop@gmail.com } \\
\text { andileo6205@gmail.com }\end{array}$ & \\
\hline
\end{tabular}

\section{INTRODUCTION}

The advancement of information technology as well as information systems and science has developed very rapidly and continue to advance in the era of globalization as now, technology and information systems today have an important role in the life of global society. The many areas of work worldwide do not escape the role of technology and information systems.For example, we can see from the education, health, governance, culture and social world that should have been such a field of work following the development of technology and information systems. The same thing happens in education, where the use of computer devices and the use of an information technology is very helpful every work process that takes place in it, whether it is seen in terms that can support their work of teachers, as well as students (students) therein. Then the use of information technology can also help and facilitate the educational institutions both academic and non academic. Later, such educational institutions will be easier in the process of development of facilities and infrastructure and human resources to be able to compete and can achieve the desired objectives in accordance with the vision and mission of each educational institution in the following 
years.A private Piano course (Samuel Rideone Piano Course) located in South Tangerang area which is located at Jalan Taman Manggu Indah Blok G4, No. 6 PondokAren, Tangerang, South Tangerang City, Banten, which already has more than 50 students in private piano courses, In this course, there are students who are not only consist of elementary schoolchildren, but there are also children who are still seated on kindergarten $(\mathrm{KG})$, and also where this course receives students for people who are already employed but have a hobby to be able to deepen their skills in the field of music, especially piano. But as with other courses, this course also has several problems that often faced such as the registration of appropriate learning time for the students, then the concert activities involving the sale/purchase of concert tickets that are less reaching the target at the time of the concert. The problem of data collection study and teaching of students is often the occurrence of error schedule or the error of teaching personnel.For example, there are students who choose the hour of study in the morning but the teacher is informed that students learn together with the teaching personnel during the day, then there was a mistake of a teacher who taught 2 to 3 disciples at the same time, then there is a teacher who is wrong teaching students with the chosen field (students choose the Classic field but the available teachers are the fields of pop).Then examples of problems at the time of the concert was in the event of the sale of concert tickets, often there was not to reach the target/absence of BEP (Break Event Point) at the time of the concert, based on the problem, it can be proposed to create a student registration information system and purchase concert tickets that can facilitate all the work processes in this private piano course that can be used for existing management.

\section{LITERATURES REVIEW}

\section{E-Ticketing}

Application of Music concert ticket purchase (E-Ticketing) aims to design information system of concert tickets selling more dynamic and modern music [1]. In the design of this information system, users will be facilitated with the way seating selection and payment methods are more flexible. The sales of music concert tickets that previously used conventional means are still not effective in terms of thorough sales so sometimes there are some problems such as lack of income that is not in line with spending to perform the musical activities. E-Ticketing is also very helpful for viewers who may not be able to make purchases of music concert tickets in conventional way then it can be through the web and can choose and watch the music concert he wants easily. E-Ticketing has also been widely used in the world of entertainment and work such as movie ticket purchases, airline ticket purchases, bus ticket purchases and more. By the existence of E-Ticketing also facilitate the management to be able to determine the policy that will be taken next, because the report that will be presented later will be done by the system, so it can minimize the mistakes that will occur.

\section{Online Registration}

Anisah, Sayuti explained that registration of new students by way of online registration can help prospective students or parents in the process of registering it easier, because they do not have to come to school and can be done anywhere, anytime [2]. As well as this online registration can help PPDB (acceptance of new students) easily and quickly find information relating to the acceptance of new students for the consideration of the management party in taking the next step or policy for the development of the learning place teaching him either school or course. This online 
registration can also suppress the expense of expenses, in this case the cost of printing the sheet registration form that was previously manual, then no longer exists, because it has already switched to a digital form. The data received will also be stored very secure and neatly arranged so that the existing data can be used as a new admission information suitable for management.

\section{Term Frequency Inverse Document Frequency (TF-IDF)}

TF-IDF is a method to calculate every word most commonly used in information retrieval [3]. This method is also known to be very efficient, easy and has accurate results. Here is the formula that is inside the TF-IDF method:

$$
\begin{aligned}
& W(t f)=\begin{array}{l}
1 \\
0
\end{array}+\log _{10}(t f) \begin{array}{l}
\text { if } t f>0 \\
\text { otherwise }
\end{array} \\
& i d f\left(t_{i}\right)=\log \frac{N}{n\left(t_{i}\right)} \\
& W_{t, d}=w(t f) x i d f\left(t_{i}\right)
\end{aligned}
$$

\section{Explanation:}

tf $=$ Frequency of Word emergence in 1 description

$t_{i} \quad=$ term/ word

$N \quad=$ Total number of descriptions

$n\left(t_{i}\right)=$ Number of descriptions containing the word(ti)

$W(t f)=\mathrm{A}$ boted $\mathrm{TF}$

\section{FRAMEWORK}

The creation of this system using XAMPP which is an instant (ready-to-serve) web server application that can be used in both Linux operating systems and Windows operating systems [4]. The Internet is also used in the creation of this system, where the internet itself is a computer network that connects between networks globally, the internet can also be called the natural network of a wide network [5]. In desain of the system, it takes a framework of thinking that becomes the main basis.

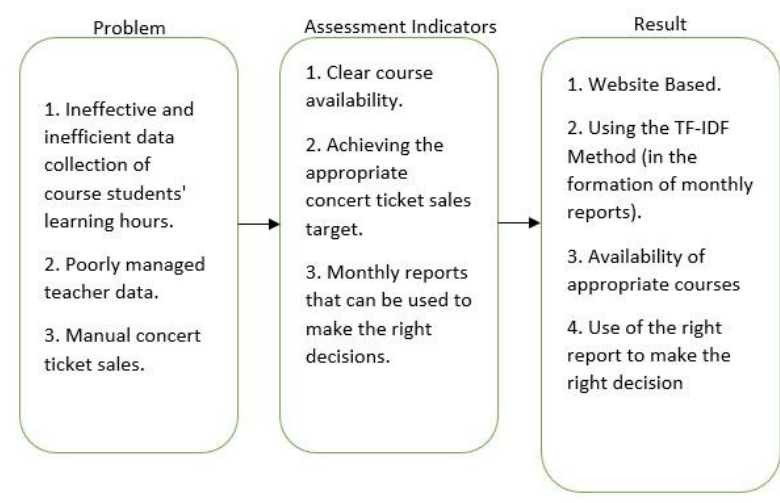

Figure 1. Framework

\section{METHODS}

\section{Use of TF-IDF method}

The use of this TF-IDF method will be applied to the running system. Where this method is focused to help management to be able to see and know the data/reports are appropriate and they need every month. It is just like to know the number of student courses that are in the first month, then the revenue from the concert ticket sales are organized and others.In terms of new users or prospective students, the application of this method is expected to help them to choose and watch concerts they like, as well as choose the course classes they are interested in.

\section{Activity Diagram of Proposed System}

Unified Modeling Language (UML) is a system development technique that uses graphic language as a tool for documenting and performing specifications on the system [6].UML is the standard language used for writing $\neg$ blueprint software. UML can also be used to visualize, specify, build and document artifacts from software systems [7].UML provides nine types of diagrams, 
others mention eight because there are several diagrams combined, such as communication diagrams, sequence diagrams and timing diagrams combined into interaction diagrams [8].To create the system that will be run, then we must know what activity the diagram will be proposed, therefore the following will be explained regarding the activity of the system diagram to be created. In the user field, to perform the course selection and buy the concert ticket, they must access the Web first, then register and get the account afterwards. Then if you have selected concerts and courses, you must make a payment and it will be validated by the admin. Once the admin has done validation, the user will get the validation message successfully. Furthermore, the admin will create a report on the course and concerts (and has been facilitated by the system) for further given to the owner. Owner will receive the report each month, and is used to take steps or other policies to develop the course.

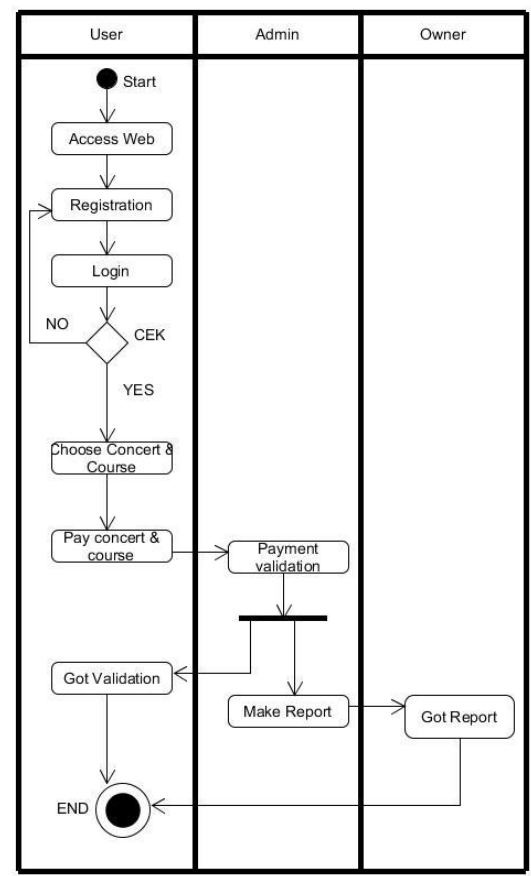

Figure 2. Activity Diagram Proposal

\section{Improved use of TF-IDF method}

After understanding the TF-IDF method and understanding the proposed diagram activity, the improvement of the method in developing the system to be created can be better. Such as example:

1. Able to determine the long term and short term decision for management.

2. Assisting management in organizing the desired report and according to the needs.

3. Helps to minimize double data, where usually double data can cause errors in system.

Certainly the development of methods and application of this system will not go well without the creativity and innovation developed as well as the technological advances that exist later. Therefore, the maintenance of system and monitoring in its implementation is very influential in the future for the advancement of this system.

\section{RESULT}

\section{Calculation method}

The following will be explained regarding the calculation method used in the design of this system. For example: For example there are Jazz, classical and Pop queries. Then there are documents such as:

1. Piano Jazz concert with Piano Pop.

2. Classical piano performance with the classic Beethoven theme.

3. Pop music performances with the theme "Indonesia Rises".

Then the weighted calculation will be done as follows: 


\section{Table 1. TF-IDF Calculation results}

\begin{tabular}{|c|c|c|c|c|c|c|c|c|c|c|}
\hline & \multicolumn{3}{|c|}{ Tf } & \multirow{2}{*}{ df } & \multirow{2}{*}{$D / d f$} & \multirow{2}{*}{ IDF } & \multirow{2}{*}{ IDF+1 } & \multicolumn{3}{|c|}{$W=t f *(I D F+1)$} \\
\hline $\mathrm{Q}$ & d1 & d2 & d3 & & & & & d1 & d2 & d3 \\
\hline Jazz & 1 & 0 & 0 & 1 & 3 & 0,477 & 1,477 & 1,477 & 0 & 0 \\
\hline Classical & 0 & 2 & 0 & 2 & 1,5 & 0,176 & 1,176 & 0 & 2,352 & 0 \\
\hline Pop & 1 & 0 & 1 & 2 & 1,5 & 0,176 & 1,176 & 1,176 & 0 & 2,352 \\
\hline & & & & & & & & 2,653 & 2,352 & 2,352 \\
\hline
\end{tabular}

Thus, it appears that in document 1 There are more words options such as jazz and pop which often appear and can be concluded that the query can help the management in front of what kind of report they want to see and they need in this system.

\section{Program View}

After knowing how to work the system made by paying attention to the implementation of the TF-IDF method in it, then the following will be displayed a program view created.

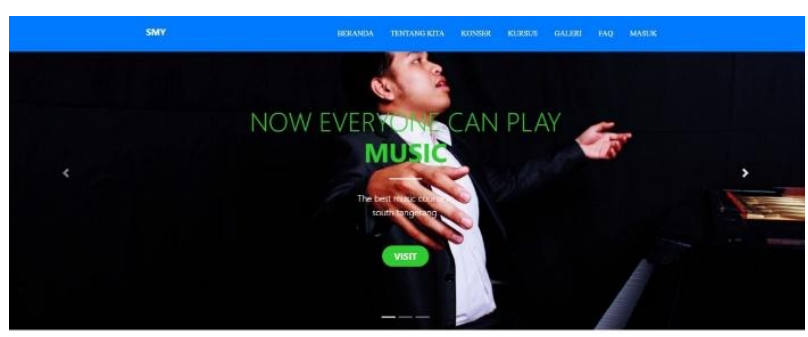

Figure 3. Home Page

In figure 3 , is the main page (homepage), when the user accesses the website.

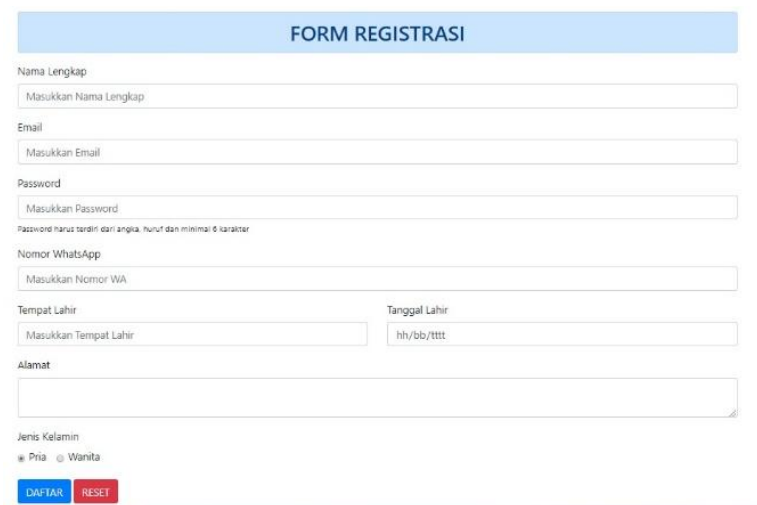

Figure 4. Registration Form
In figure 4, is a registration Form for new users.

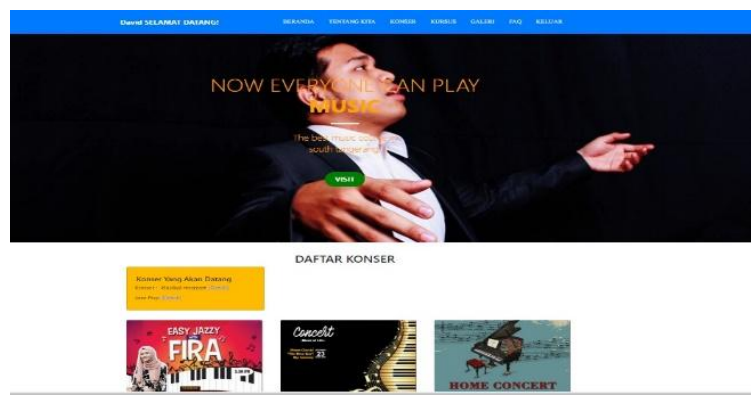

Figure 5. Concert page

In figure 5, is a picture of a concert page, where the user can choose the concert to watch.

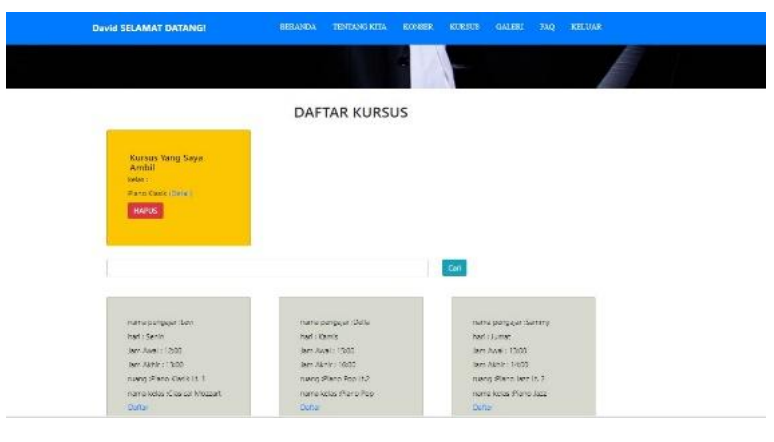

Figure 6. Courses page

In figure 6 , is a course page where users can choose the course they are interested in..

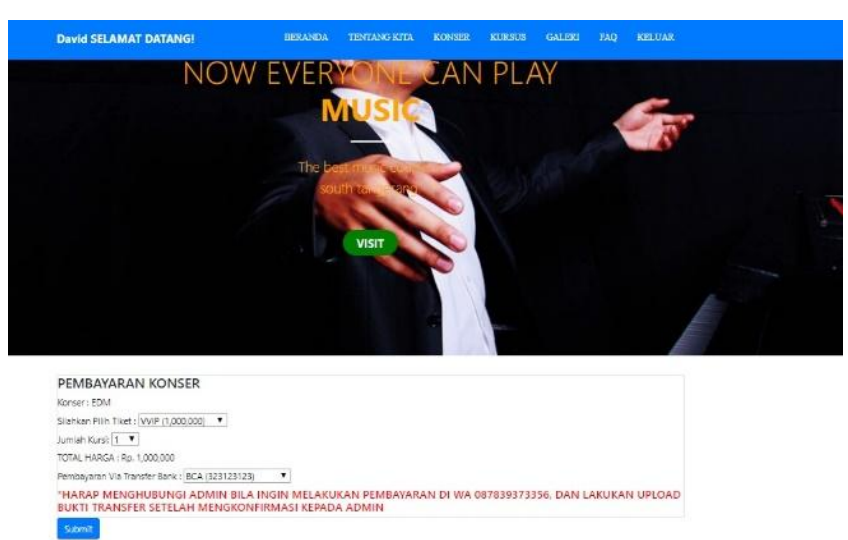

Figure 7. Courses and Concerts Payment page

In figure 7 , is the concert payment page and the course that the user has chosen. 


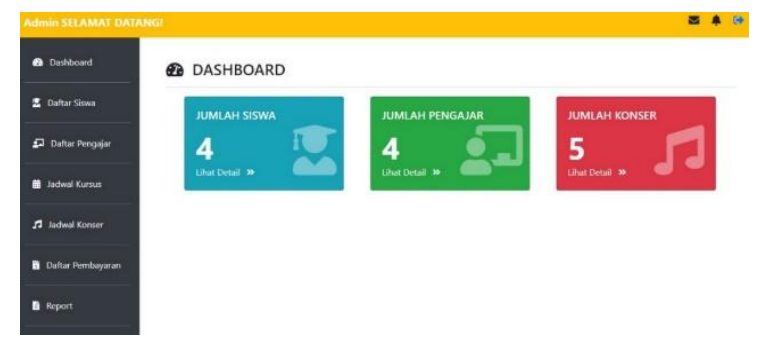

Figure 8. Admin Home Page

In figure 8 ,is the admin's main page, and there are menus that admins can use, such as validating payments, generating monthly reports, viewing existing student data, adding classes, adding concerts, and more.

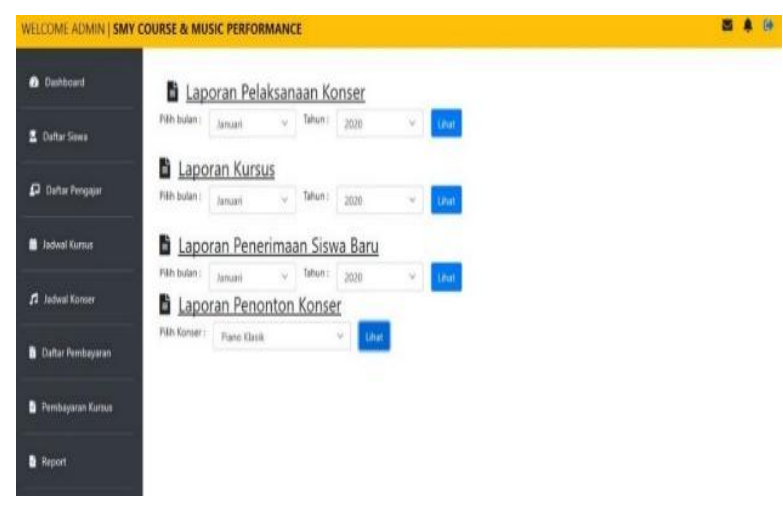

Figure 9. Report Menu Admin Page

In figure 9, is the report menu found on the admin page. There is a choice of reports that an admin can use to give it to management. Like new student admissions reports, concert and other implementation reports.

\section{CONCLUSION}

Designing of new Student information system and purchasing concert tickets, already in accordance with the needs and problems that arise at the course of Samuel Riedone Course \& Music Performance. And also with the new student registration system and the purchase of concert tickets based on this website, it is easy for users to make purchase transactions for music concert tickets, and register themselves to be able to follow the course at this place. And the resulting report is very helpful to the management to be able to conduct more policies on this course. 



\section{REFERENCES}

[1] Wahyudi, "Application Development of Music Concert E-Ticketing System With Seating Number On Motikdong.com Website," Journal of Informatics Engineering (JIKA), vol. 4, pp. 20-27, 2020.

[2] S. Anisah, "Designing the Online Registration Information system for new WEB-based student admissions at the State SMK 1 Kelapa Bangka Barat," SISFOKOM Journal, vol. 07, no. 2, pp. 174-179, 2018.

[3] R. Melita, V. Amrizal, H. B. Suseno dan T. Dirjam, “Application of Term Frequency Inverse Document Frequency Method,” Journal Of Informatics Engineering, vol. 11, no. 2, pp. 149164, 2018.

[4] I. P. Bagus, Eka, Pratama, Information System and Implementation, Bandung: Informatics Bandung, 2014.

[5] A. F. Sibero, Scripture Programing, Yogyakarta: Mediakom, 2011.

[6] Mulyani, Method of Analysis and System Design, Bandung: Abdi Sistematika, 2016.

[7] A. Yadanur, "Development of Patient Screening Administration Information System in The Installation of Radiology of Kajen Hospital with Unified Process, " Journal of Informatics Society, vol. 2, pp. 27-36, 2012.

[8] H. Widodo ,Using UML, Bandung: Informatics, 2011.

\section{BIOGRAPHY}

Peryo Suliantino, A graduate of the Buddhi Dharma University with an Information System study Program in 2020, now an employee at the Buddhi Dharma University.

Andi Leo, obtained his Bachelor of Computer degree at Bina Nusantara University in 1989. And earned his Masters of Computer at BundaMulia University in 2004. Now currently a Lecturer in Information Systems Study Program, Buddhi Dharma University. 